building annelid, evidently formed out of the gritty matter which occurs, though sparingly; in the clay. The tubes with their contents were handed over to Dr. v. WillemoesSuhm, who found the worms to belong to the family Ammocharidx (Claparéde and Malmgren), closely allied to the Maldania or Clymenidx, all of which build tubes of sand or mud. The largest specimens dredged are 120 $\mathrm{mm}$. in length by $2 \mathrm{~mm}$. in width. The head is rounded, with a lateral mouth. There is no trace of cephalic branchiæ. The segments are not divided from one ancther; but the tori ancinigeri, which are occupied by the hair-like setre, and the elevations bearing small uncini, indicate the beginning of a new segment.

There is no doubt that this annelid is closely allied to the genus Oivenia, but it differs from it in the absence of cephalic branchize. Malmgren, has, however, already proposed the name of Myriochele for a form in which this absence of branchia occurs. The description of the northern form on which Malmgren's genus is founded is not at hand, so that it is impossible in the meantime to determine whether the two forms are identical or specifically distinct.

As bearing upon some of the most important of the broad questions which it is our great object to solve, I do not sec that any capture which we could have made could have bcen more important and more conclusive than that of this annelid. The depth was 2,975 , practically 3,000 , fathoms - a depth which does not appear to be greatly exceeded in any part of the ocean. $\mathrm{Th}_{4} \mathrm{e}$ nature of the bottom, which consists of a smooth red clay with a few scattered sand grains and a very small number of foraminifera shells, was very unfavourable to higher animal life, and yet this creature, which is closely related to the Clymenidx, a well-known shallow-water group of high organisation, is abundant and fully developed. It is fortunate in possessing such attributes as to make it impossibie even to suppose that it may have been taken during the passage of the dredge to the surface, or have entered the dredge-bag in any other illegitimate way; and its physiognomy and habits are the same as those of allied forms from moderate depths. It affords, in fact, conclusive proof that the conditions of the bottom of the sea to all depths are not only such as to admit of the existence of animal life, but are such as to allow of the unlimited extension of the distribution of animals high in the zoological series, and closely in relation with the characteristic faunæ of shallower zones.

On Thursday the $13^{\text {th }}$ our position at noon was lat. $18^{\circ}$ $54^{\prime} \mathrm{N}$., long. $61^{\circ} 28^{\prime} \mathrm{WV}$.

On the forenoon of the 14 th we were still 35 miles from land, and we sounded in 1,420 fathoms. The bottom had altered greatly in character : it now consisted chiefly of calcareous foraminifera of many species, mixed with a considerable portion of the broken spicules of siliccous sponges. The bottom temperature registered was $3^{\circ} \mathrm{C}$. The water-bottle was accidentally broken in taking in, so that that observation was lost. As we were now within sight of land, and all our results were evidently modified by its immediate proximity, we regarded our first deep-sea section as completed.

WYVILLE THONISON

\section{A MODERN STERNBERGIA}

$A^{\mathrm{T}}$ T 2 time when botanists of some repute are not ashamed to confess their inability to deduce satisfactory characters for the determination of plants from their internal anatomy, old workers in this field may. well turn back to refresh their memories on such points, and to inquire whether their eyes may not have deceived them in the investigations of former ycars when microscopes were not what they now are. In doing this a few days ago in connection with the examination of a carboniferous conifer, I was surprised to find that I had overlooked or omitted to note the fact that the Balsam Fir of Canada (Abic's bal- samea), which affords the well-known Canada-balsam, has that curious structure of pith well known in Palxozoic Conifers, and which has been named Sternbergia. It is well seen in young twigs one or two years old, and though on a smaller scale, is very similar to that of Dadorylon matcriarium of the upper coal-formation of Nova Scotia and Prince Edward Island, as I have figured this in my recent report on the geology of the latter province.

This modern Sternbergia is not produced by the mere breaking of the cellular tissue transversely by elongation of the fibre; but, as I pointed out many years ago in the case of the coal-formation Sternbergix, ${ }^{*}$ is a true organic partitioning of the pith by diaphragms of denser cells opposite the nodes, as in Cecropia pellata, and some species of Ficus, Scc. The pith of the Balsam Fir is, like that of many other conifers, composed of dotted or transversely marked cells elongated vertically, and reminding one of the pseudo-vascular pith of some Lepidodendroid trees. The transverse diaphragms are composed of denser cells flattened horizontally, and they are, as in Sternbergia, accompanied by constrictions of the medullary cylinder. As in some fossil conifers, the diaphragms are not perfectly continuous.

The plan of growth of the modern fir does not permit its pith to increase in diameter. This was different in the Paleozoic conifers, in which the Sternbergia pith is sometimes nearly two inches in diameter.

In Palxozoic, as in modern times, Sternbergia piths were not confined to one family of trees. Corda has shown this structure in Lomatophloios, which is equivalent to Lepidophloios or Ulodendron. I have shown that it exists in several species of Lepidodendroid and Sigillaroid trees and in Leptophleum.t Williamson, who first established it in the Conifers, has also found it in Dicty'oxylon. Still I have nowherc found these remarkable fossils so abundant as in the upper coal-formation, and either in the interior of calcified or silicified trunks of pine or with fragments of wood attached to them sufficient to indicate their coniferous character.

I may add, that the microscopic structure of young twigs of modern conifers presents many interesting points for comparison with fossil trees, and that in making longitudinal slices of the pith of recent specimens, care should be taken not to be misled by the merc crumpling of the celiular tissue sometimes caused by the pressure of the knife.

J. WV. DAWSON

\section{NOTES}

Professor CARUs, the well-known naturalist of Leipsic University, who is to fill Professor Wyville Thomson's chair during the absence of the latter with the Challenger, commenced his duties on May 2 last, by an able and eloquent address on the study of zoology. He is fully convinced that "the final form of our (zoological) system will be a pedigree."

THE. Challenger arrived at Halifax on May 9, all well. She had a successful passage from Bermuda, the dredgings and soundings being very satisfactory. On the 18 th inst. she will leave this port on a return voyage to Bermuda.

Wrri great regret we record the death of Mr. John Stuart Mill, at the age of 67 years, on Mray 8 , at $A$ vignon, from a suctden attack of erysipelas, which cut him off in four days. He has been buried beside his wife at Avignon. A meeting of the friends of Mr. Mill has been convened, at IVillis's Rooms, for 'Tuesday, 2oth inst., to consider in what manner the national respect for his memory may be most fittingly testified.

A Coymittee for the erection of a monument to Licbig has been constituted at Munich. Councillor von Niethanmer is the chairman, Prof. Von Bischoff the vice-chairman, and Professors - Canadian Naturalist and Geologist, 1837. t Journal of the Geoleg:cal Socic:s, May iôts. 